\title{
Cooperative Societies and Sustainability: A Spatial Analysis of Andalusia as a Tool for Implementing Territorial Development Policies, Strategies and Initiatives
}

\author{
María del Carmen Pérez-González ${ }^{1}$ (D) and Lidia Valiente-Palma ${ }^{2, *}$ \\ 1 Department of General Economy, University of Cadiz, 11002 Cádiz, Spain; maricarmen.perez@uca.es \\ 2 Department of Applied Economics I, University of Seville, 41018 Sevilla, Spain \\ * Correspondence: lvaliente@us.es
}

check for

updates

Citation: Pérez-González, M.d.C.;

Valiente-Palma, L. Cooperative

Societies and Sustainability: A Spatial

Analysis of Andalusia as a Tool for

Implementing Territorial

Development Policies, Strategies and

Initiatives. Sustainability 2021, 13, 609.

https://doi.org/10.3390/su13020609

Received: 16 November 2020

Accepted: 28 December 2020

Published: 10 January 2021

Publisher's Note: MDPI stays neutral with regard to jurisdictional clai$\mathrm{ms}$ in published maps and institutional affiliations.

Copyright: () 2021 by the authors. Licensee MDPI, Basel, Switzerland. This article is an open access article distributed under the terms and conditions of the Creative Commons Attribution (CC BY) license (https:// creativecommons.org/licenses/by/ $4.0 /)$.

\begin{abstract}
Local development strategies, policies and initiatives that contribute to sustainable development are gaining increasing prominence. Cooperative societies-the most relevant organisations within the social economy-are widely present in Andalusia and play a key role in boosting sustainable development through their principles and values. On this basis, the article aims to determine whether certain areas in Andalusia are more predisposed to the presence of these enterprises and are more sustainable as a result. The methods used include an adapted shift-share analysis and application of local Moran's I to obtain spatial clusters allowing the areas most favourable to the presence of this type of organisation to be identified. Therefore, one of the main contributions of the study is that it provides a tool for the application of local development policies, strategies and initiatives involving cooperatives in pursuit of a more sustainable society.
\end{abstract}

Keywords: Andalusia; cluster analysis; cooperative societies; local development initiatives; local Moran's I; shift-share analysis; sustainability territorial development

\section{Introduction}

In recent decades, a series of global developments have occurred that have impacted both positively and negatively on local economies: mismanagement of globalisation has led to worsening economic malaise in some regions, producing growing social inequalities which various agencies (especially international institutions) have been unable to address; cultural elements and regional identities are gradually being lost and financial liberalisation in pursuit of a speculative economy has prioritised capital over workers and weakened the norms and institutions that protect them. Moreover, nation states have lost the sovereignty to tackle problems arising within their borders [1,2].

It may be argued that inadequate management of globalisation and widespread market liberalisation (deregulation) policies have distanced people from the land, consumers from producers, and the economy from society [3].

Among the most serious problems caused by the current international socioeconomic situation and dominant development models are environmental pressures and a lack of socioeconomic commitment from companies to their respective surroundings, hindering progress towards sustainable territorial development. Here, sustainability is understood in a holistic sense, encompassing social, economic, environmental, cultural and territorial aspects.

In this context, regions must respond by managing and harnessing their resources in an innovative manner [4]. In this regard, cooperative societies, which are among the most representative organisations in the social economy, offer an opportunity to forge closer links between societies and the land based on the principles and values underpinning them and their activity.

According to the International Cooperative Alliance, cooperative societies are "peoplecentred enterprises owned, controlled and run by and for their members to realise their 
common economic, social, and cultural needs and aspirations" (http:/ /ica.coop/en/whatco-operative).

Similarly, Article 2 of Law 14/2011 of 23 December on Andalusian Cooperative Societies (modified by Law 5/2018 of 19 June) defines these organisations as "democratically organised and managed enterprises that carry out their activities in a responsible manner in solidarity with the community and whose members, as well as holding equity, participate in the enterprise's activities by providing labour, satisfying consumption or using its services to add value to their own business activity".

Among the values and principles that promote sustainability in the activities of cooperative societies are democracy; social engagement; solidarity; responsibility; allocation of surpluses to sustainable development; fighting social exclusion; promoting self-employment [5]; promoting equal opportunities for men and women; social cohesion; reconciling work, personal and family life and sustainability [6].

As a product of their socioeconomic context, these enterprises are closely linked to the regions in which they operate [7-12] and this is where most of their activity takes place, contributing to the sustainable development of these areas.

In this regard, a number of studies have conducted spatial analyses of cooperativism or its impact on a region [13-17].

Drawing on the premise that cooperatives contribute to sustainable development, the aim of this article is to determine whether some areas are more predisposed to the presence of cooperatives in their business communities due to the endogenous resources available.

In order to fulfil this aim, the article focuses on Andalusia, a Spanish autonomous community that is economically underdeveloped compared to other regions in Spain and has a significant proportion of cooperatives in different economic sectors.

Andalusia's underdevelopment relative to the rest of Spain is evidenced by a number of social indicators: the region had an unemployment rate of $21.32 \%$ in the second quarter of 2020, 6 percentage points above the Spanish average [18], while the at-risk-of-poverty rate (percentage of the population living below the at-risk-of poverty threshold which measures inequality rather than absolute poverty. It determines the number of people with low incomes as a proportion of the total population. The at-risk-of poverty threshold is set at $60 \%$ of the median income per consumption unit.) stood at $31.3 \%$ in the 2019 Survey on Living Conditions compared to a national average of $20.7 \%$.

With regard to the presence of a significant number of cooperatives in the region, data from the Ministry of Employment and Social Security for 2019 show that 22\% of cooperatives in Spain are located in Andalusia, providing $24 \%$ of all employment generated by these enterprises in the country.

Following this introduction, a conceptual framework for analysing the most significant aspects of the contribution made by the social economy to sustainable territorial development is presented. A shift-share analysis is then carried out and a spatial analysis method is applied: local Moran's I, which is a local indicator of spatial association and allows spatial clusters to be obtained from the study variables. The methodology used was designed to study cooperative societies in Andalusia and ascertain the presence of factors encouraging the location of these enterprises in certain parts of the region, which fulfil their needs as a result of the endogenous resources they possess. The results of the analysis are then discussed and the most important conclusions and contributions made by the study are collated; this article concludes that more favourable environments for social economy enterprises based on local characteristics do exist when compared to the rest of Andalusia.

In short, this article demonstrates that cooperative societies can contribute to sustainable development and that certain parts of Andalusia are significantly more predisposed to the presence of these cooperatives, providing an opportunity (or justification) for applying local policies and initiatives aimed at boosting sustainable development through these organisations. 


\section{Conceptual Framework: Social Economy and Sustainability}

Contemporary development models should aim to promote local development by drawing on resources specific to regions, participation and networking by territorial stakeholders and formal and informal regulations as factors that constitute their potential for growth and development, based on governance in which local stakeholders and communities play an active role. This type of development is endogenous, provoking structural change as a result of regions' internal capacities, involving active participation and engagement from stakeholders, and harnessing the benefits of globalisation-factors external to the creation of competitiveness - at a local level in a sustainable, responsible manner [19-22].

Reinforcing this perspective, the neo-endogenous approach to development emphasises the role of governance and the importance of local stakeholders and communities in local decision-making, taking external influences and experiences into consideration [23,24]. Within this neo-endogenous current, numerous studies have explored different aspects of rural areas and different locations. These include a study of holistic rural development with a neo-endogenous focus in northern Scotland [25]; an analysis of housing and rural development in Ireland, which can be extrapolated to other locations [26]; an analysis of LEADER in the UK, exploring the empowerment of local stakeholders to participate in developing their own areas [27] and the practices, problems and impacts involved in neo-endogenous rural development within the European Union [28].

Sustainability is a central part of these models. The traditional concept of sustainability, viewed in largely environmental terms, has been superseded by a broader understanding of the term, which is multifaceted and holistic [29], considering economic, social, cultural and environmental aspects, among others, to be part of sustainable territorial development.

As part of the 2030 Agenda (https:/ / www.un.org/sustainabledevelopment/es / 20 15/09/la-asamblea-general-adopta-la-agenda-2030-para-el-desarrollo-sostenible/), the MDGs (https://www.undp.org/content/undp/es/home/sdgoverview/mdg_goals.html), followed by the SDGs (https: / / www.un.org/sustainabledevelopment/es / objetivos-dedesarrollo-sostenible/), present sustainability as the product of individual, corporate, institutional, social and territorial behaviours, which must be coordinated and structured by various territorial stakeholders. Each region must take responsibility for its own evolution and development. In this context, sustainability is based on the ability to identify, monitor and boost the factors producing endogenous development [22]. According to Vázquez [30] (preface, XI), societal changes since the mid-1970s have resulted in a change to business organisations, which have become more flexible and more integrated into local areas, and to their location decisions. In turn, this is transforming spatial development models.

Participation from different territorial stakeholders-institutions, companies and citizens, among others-is fundamental for territorial development [22,31]. These stakeholders should interact dynamically with one another and be able to adapt to ongoing changes in the activities taking place in the region [32]. Their responses, involvement and commitment to sustainable development in the places where they operate help regions to progress using their own endogenous resources. One of these stakeholders-social economy enterprisesplays a key role as an agent of development [33], contributing to sustainable development through the principles and values guiding their own management and activities [34,35].

This study focuses on cooperative societies, the most prominent organisations in the social economy, as territorial stakeholders that can play a hugely significant role in sustainable territorial development as a result of their own values, principles and characteristics.

The activities carried out by social economy organisations can improve their response to the community's needs, their ongoing engagement with the setting in which they operate and their ties to the local area, inhibiting their relocation; cooperatives prioritise social and environmental activities rather than strict profitability considerations, so they do not move from one place to another [36]. Indeed, cooperatives work in a specific area and reinvest their profits in that same area, with a positive multiplier effect on the places where they operate $[37,38]$ that contributes to more sustainable development. 
Previous studies in other locations have examined the contribution made by cooperatives to territorial development and emphasised their role in rural policymaking, focusing on Spain [39] and the regional development cooperative initiative in rural areas of Quebec [40]. These enterprises may be viewed as agents of development [33]. Given this, if certain areas are predisposed to the emergence of social economy organisations in their production systems due to their endogenous characteristics, then it may also be more likely that sustainable development (understood in a holistic sense, encompassing social, economic, environmental, cultural and territorial aspects) is taking place in these areas.

Cooperation between different territorial stakeholders-companies, institutions and citizens opting for entrepreneurship and self-employment—can help to meet the needs of the socioeconomic context and contribute to sustainable territorial development in Andalusia. Here, sustainability is understood in a holistic manner: in the broadest sense, regions that encourage interaction and coordination between local stakeholders are more committed to the environment and boost environmental sustainability; by nurturing, protecting, preserving and disseminating a regional identity and values, they also promote cultural sustainability; by fomenting collective self-employment among women and young people [41,42], who are at greater risk of social exclusion, they work to ensure labour, social and gender sustainability; by remaining solid in times of crisis, they contribute to economic sustainability as cooperatives offer a way of life rather than just a job.

Therefore, a cooperative is (or should be) a company that draws on its principles to carry out activities aimed at promoting overall and specific sustainability, serving as an ideal tool for implementing local development initiatives.

The presence of social economy enterprises, in general, and cooperatives, in particular, in local production systems depends on the endogenous resources available in each region. Through their values, principles and characteristics, these enterprises can help to improve social, economic and territorial cohesion and sustainable development, especially in rural environments [43].

Cooperatives play a key role in developing disadvantaged socioeconomic contexts, focusing on sectoral dimensions with clear territorial projection, as well as creating and consolidating social capital in rural areas, providing added value in response to challenges and difficulties arising in the rural environment [44].

The Official State Gazette published on 14 December 2007 contained notification of Law 45/2007 of 13 December on Sustainable Development of the Rural Environment, which aims to encourage activities that are compatible with sustainable development through diversification, as well as to protect employment and revenues in sectors typical of rural areas (agriculture, livestock farming, forestry, fishing), among other measures. According to Article 1 of the law, it provides a basis for "regulating and establishing measures to promote sustainable development in rural environments, as long as they provide the basic conditions necessary to guarantee equality for all citizens in the exercise of certain constitutional rights and lay the foundations for the overall development of economic activity in these environments".

The law establishes three types of rural areas: the rural environment, which refers to a group of municipalities or local entities with an overall population not exceeding 30,000; the rural area, which constitutes the area of application for the measures regulated by the law and is to be defined by each autonomous community based on district or subprovincial units and the small rural municipality, with a population under 5000, which forms part of a rural environment.

According to data from the Institute of Statistics and Cartography of Andalusia (IECA), more than $66 \%$ of the region is made up of municipalities with populations not exceeding 5000 inhabitants, so rural environments are predominant in the region.

Therefore, given the widespread presence of cooperatives in Andalusia, the contribution made by these enterprises to sustainability, and the predominantly rural environment, social economy organisations may be said to play a key role in development policies in the region and in local development initiatives more specifically. For this reason, it is relevant 
to explore whether certain parts of the region offer comparative advantages to cooperative societies, or, in other words, whether they offer better conditions for these organisations to develop within their business communities and local production systems.

This topic has been the subject of many studies focusing on different regional conditions and their role in explaining spatial disparities in different regions around the world. For example, Silva [45] suggests that new location factors are becoming more prominent in the new world order resulting from globalisation, identifying different regions as winners or losers depending on their particular characteristics. Aché [46] summarises the main theories seeking to account for the formation of regional inequalities. Meanwhile, OrtizPérez [47] focuses on "the production of space", emphasising cooperativism as a highly significant geographical factor with a role in regional development. Todes and Turok [48] trace the international debate surrounding solutions to spatial inequalities with a focus on South Africa, a country with marked spatial differences and growing political pressure for change.

As for European case studies, Lo Cascio, Mazzola, Di Giacomo and Epifanio [49] analyse the regional capital of different Italian provinces and their ability to respond to crises, identifying significant spatial heterogeneity. Mastronardi, Giagnacovo and Romagnoli [50] explore a new business model_community-based cooperatives-that makes an important contribution to regional development in rural Italy, highlighting the need to reconsider regional policies and planning. Filippi, Triboulet, Chantelot and Peres [51] demonstrate high global and local spatial autocorrelations in the geographic location of French agricultural cooperatives. In the Andalusian case, Sánchez-Zamora and Gallardo-Cobos [52] analyse territorial resilience in rural Andalusia in response to the 2008 crisis, exploring the factors shaping certain territorial dynamics and identifying significant diversity between rural areas.

Therefore, significant regional diversity exists and is determined by a wide variety of social, economic, political, environmental and cultural factors of a domestic nature, as well as by external factors. As a result, areas may be developed to offer more attractive features for the implementation of certain activities.

On this basis, this article analyses the more favourable conditions for cooperativism that are present in some parts of Andalusia. Given the principles and values that cooperatives tend to apply in their work, these areas could contribute to more sustainable territorial development.

\section{Methodology}

As indicated at the start of this paper, Andalusia is a Spanish autonomous community with significant underdevelopment compared to the rest of Spain, as indicated by the evolution of its unemployment rate (Figure 1) and at-risk-of-poverty rate (Figure 2).

However, it is also one of the regions with the highest number of cooperative societies in Spain; in 2019, Andalusia accounted for 22\% of cooperative societies in Spain and 24\% of the total employment provided by these organisations. This interest in cooperativism and in the social economy, in general, is also present institutionally, with initiatives such as the Andalusian Pacts for the Social Economy and various programmes to support social economy organisations. The last pact was signed in the midst of the recession in 2011 and its objectives include the promotion of the principles and values of the social economy, support for the creation of sustainable companies, quality employment and economic and social cohesion.

As noted above, a number of studies have conducted spatial analyses of cooperativism or its impact on a region [13-17]. 


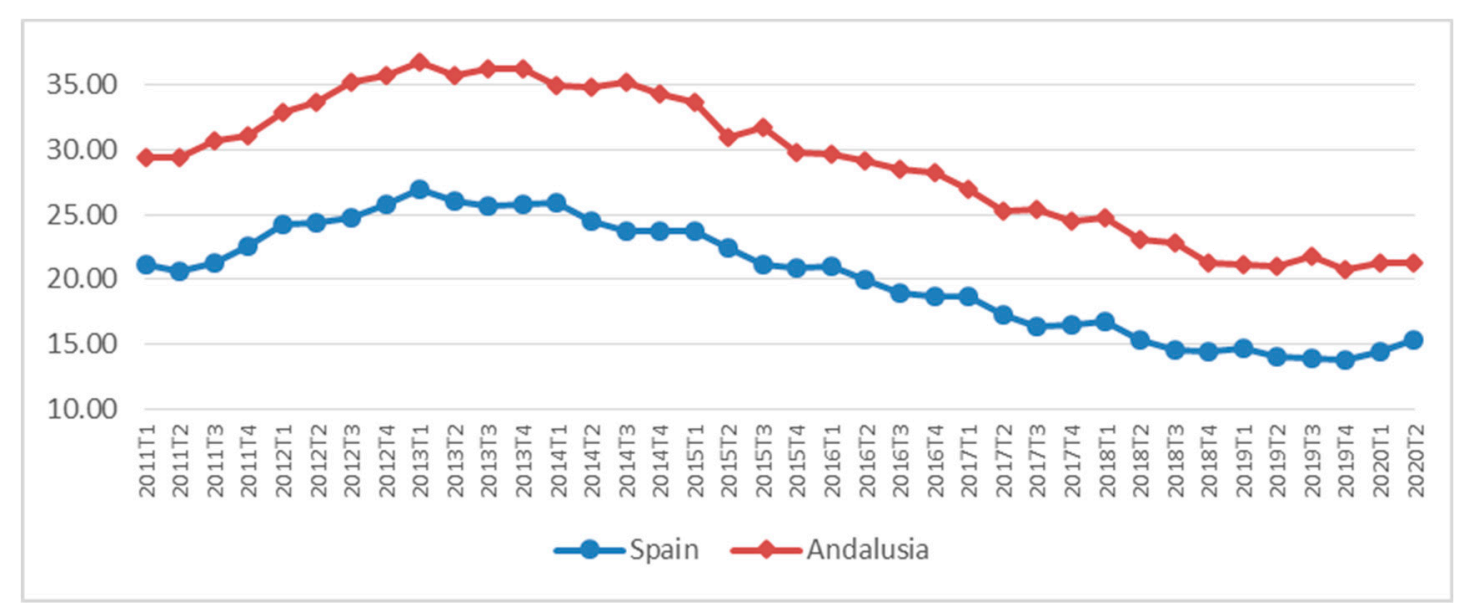

Figure 1. Evolution of quarterly unemployment rates in Spain and in Andalusia Source: Compiled by the authors using the Economically Active Population Survey published by the Spanish National Statistics Institute (INE).

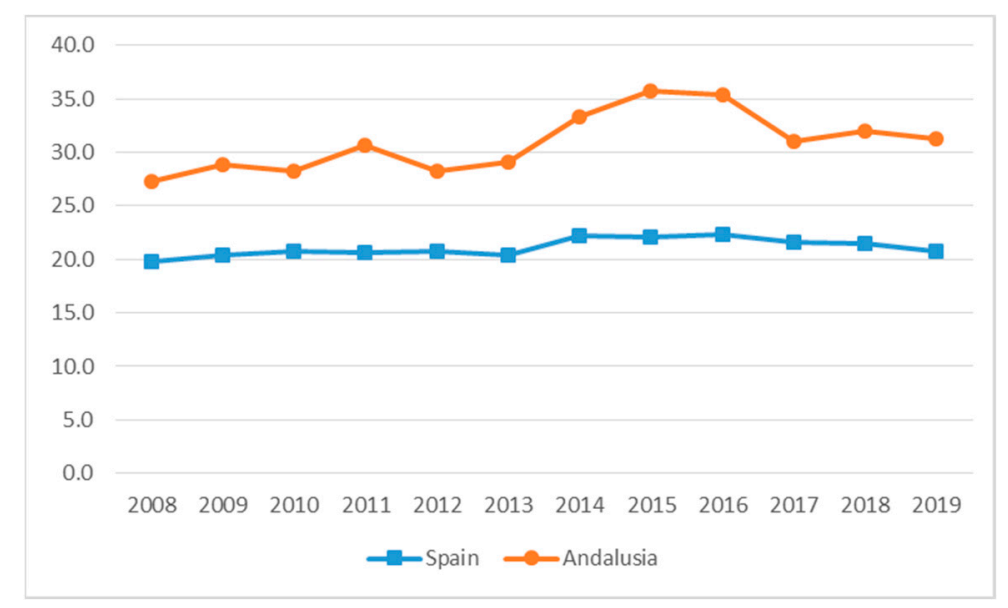

Figure 2. Evolution of at-risk-of-poverty rate in Spain and in Andalusia. Source: Compiled by the authors using the Survey on Living Conditions published by the Spanish National Statistics Institute (INE).

Cuadrado and Ciruela [14] explore the Andalusian case study, showing how social economy enterprises are becoming increasingly prominent in quantitative terms and in terms of their capacity to provide stable, quality employment, particularly during periods of crisis. In a similar vein, Blanco [16] demonstrates that the negative impact on employment in cooperative societies in Andalusia has been lower than in the rest of the business community during economic recessions.

Rodríguez-Cohard, Mozas and Bernal [13] highlight the role of cooperatives in the process of productive change and economic diversification in their study of Bedmar, a small municipality in the province of Jaén.

Meanwhile, Galdeano-Gómez, Pérez-Mesa and Godoy-Durán [15] focus on the southeast of Spain and reveal the ways in which cooperatives can generate synergies combining different dimensions of sustainability, showing the relationship between cooperativism and territory. Similarly, Pérez and Valiente [17] also study the case of Andalusia and demonstrate that cooperative societies display closer ties with the places in which they operate than more conventional companies, so it is particularly valuable to include them in territorial development policies.

Based on the results of the aforementioned studies, which have shown the capacity of cooperative societies to maintain stable, quality employment, their closer links to place, which allow them to respond more efficiently to the community's needs, and their rela- 
tionship with sustainability, this study aims to provide a tool for the application of local development initiatives, policies and strategies for sustainable territorial development involving cooperative societies.

In order to do this, however, we must take into consideration the territorial diversity present in Andalusia [53-56]. The Andalusian Regional Development Reports (IDTA) are highly illustrative in this respect, determining and differentiating levels of development in different areas of Andalusia based on their resources and their socioeconomic and environmental conditions. The latest (third) report aimed to provide an overview of territorial development in Andalusia and its evolution over time on the basis of three key components: environmental or natural, economic and social [56]. The report identified different territorial areas in Andalusia based on their level of development, including coastal and urban areas with dynamic economies and environmental pressures, predominantly highland areas with environmental and social resources but low economic activity and areas with high employability and moderate environmental and social resources [56] (p. 330). This diversity demonstrates the need to consider the particular characteristics of each region when applying development strategies and policies to Andalusia.

Performing a spatial analysis of cooperativism, this study makes a methodological contribution by adapting the shift-share analysis [57] to allow an assessment of the proportion of cooperative societies in relation to the total number of companies and obtain a more detailed overview of cooperativism in Andalusia.

As a spatial effect, the municipalities where cooperativism displays a competitive advantage relative to the autonomous community of Andalusia were identified. The equation defining the spatial effects for each municipality is:

$$
g-G=\sum_{k=1}^{j} e_{k}\left(G_{k}-G\right)+\sum_{k=1}^{j} e_{k}\left(g_{k}-G_{k}\right)
$$

where $g$ is the level of cooperativism in a specific municipality in Andalusia and $G$ is the level of cooperativism for the region of Andalusia as a whole, the effects break down as follows:

$$
\frac{C_{i}}{T_{i}}-\frac{C_{A}}{T_{A}}=\sum_{k=1}^{j} \frac{T_{k i}}{T_{i}}\left(\frac{C_{k A}}{T_{k A}}-\frac{C_{A}}{T_{A}}\right)+\sum_{k=1}^{j} \frac{T_{k i}}{T_{i}}\left(\frac{C_{k i}}{T_{k i}}-\frac{C_{k A}}{T_{k A}}\right)
$$

where $i$ is the municipality under study, $A$ is the autonomous community of Andalusia, $k$ is the productive sector, $C$ is the number of cooperatives and $T$ is the total number of companies.

The difference between the level of cooperativism in a municipality-measured as the proportion of cooperatives in the total number of companies-and the level of cooperativism in Andalusia as a whole $\left(g-G=\frac{C_{i}}{T_{i}}-\frac{C_{A}}{T_{A}}\right)$ can be broken down into two effects:

1. a structural effect $\left(\sum_{k=1}^{j} e_{k}\left(G_{k}-G\right)=\sum_{k=1}^{j} \frac{T_{k i}}{T_{i}}\left(\frac{C_{k A}}{T_{k A}}-\frac{C_{A}}{T_{A}}\right)\right)$, owing to the productive composition of cooperativism in the municipality compared to Andalusia overall, or in other words, to the proportion of cooperatives in different productive sectors, and 2. a residual or differential effect $\left(\sum_{k=1}^{j} e_{k}\left(g_{k}-G_{k}\right)=\sum_{k=1}^{j} \frac{T_{k i}}{T_{i}}\left(\frac{C_{k i}}{T_{k i}}-\frac{C_{k A}}{T_{k A}}\right)\right)$, which represents the comparative advantage for cooperativism compared to Andalusia as a whole, that is, whether the municipality has specific characteristics that give rise to higher levels of cooperativism in comparison with the rest of the region. If this residual or differential effect is positive $\left(g_{k}>G_{k}\right)$, then municipality $i$ has a comparative advantage for cooperativism; on the contrary, if it is negative $\left(g_{k}<G_{k}\right)$, there is no comparative advantage compared to the rest of Andalusia.

This study focuses particularly on the second residual or differential effect, also referred to as competitive, which compares the proportion of cooperatives in a municipality with the total number of companies with that value in Andalusia for each of the productive sectors. If the effect is positive, the municipality offers location benefits for cooperativism 
in relation to the region of Andalusia as a whole. For example, a productive sector in a particular municipality may experience specific socioeconomic characteristics that encourage the presence of cooperativism, so that area will offer a series of benefits compared to the rest of the region.

Subsequently, local Moran's I was applied to the results obtained to identify the environments that were favourable to this competitive effect, where positive synergies occur as a result of the location benefits for cooperativism that are present. This indicator is a local indicator of spatial association (LISA), which allows spatial groups or clusters to be obtained for a specific variable. In this case, the application of this indicator served to identify favourable environments for cooperativism. Here, "favourable environment" refers to a specific group of adjoining municipalities that may share economic and inter-territorial synergies. Identifying these environments provides justification for the implementation of local development initiatives, policies and strategies to promote sustainable development in Andalusia, with cooperative societies acting as agents or promoters of this development.

The local Moran's I, which is calculated for every municipality in Andalusia, $i$, is defined as follows [58]:

$$
I_{i}=\frac{\left(y_{i}-\bar{y}\right)}{\sum_{i=1}^{n}\left(y_{i}-\bar{y}\right)^{2} / n} \sum_{j=1}^{n} w_{i j}\left(y_{j}-\bar{y}\right) \text { for } i \neq j
$$

What occurs in $i$, in relation to the reference variable, is a function of the values of the variable in its neighbouring or nearby locations, $j$. In other words, the aim is to calculate the local Moran's I for each municipality, determining the degree of similarity between the municipality and its neighbours. When applying the indicator, a first-order spatial lag with queen-type contiguity was used; that is, municipalities are considered to be adjacent or adjoining when they have a point in space in common.

This local indicator is standardised [59]: $Z\left(I_{i}\right)=\frac{I_{i}-E\left(I_{i}\right)}{\sqrt{V\left(I_{i}\right)}} \sim \mathrm{N}(0,1)$, where $E\left(I_{i}\right)$ is the mean value of $I_{i}$ and $V\left(I_{i}\right)$ is its standard deviation. If $Z\left(I_{i}\right)$ is statistically significant, the existence of a specific spatial cluster or group can be confirmed.

The results are displayed on a map, which shows the clusters produced when a municipality with a high (or low) value for the variable is close to municipalities with values that are also high (or low) - areas with similar values - and atypical or extreme values - areas with different values- [60].

The methodology employed here is of particular interest as it is based on the premise that Andalusia is highly diverse and takes into consideration the spatial location of the data within the region.

With regard to the data used, the study focused on the variables "number of cooperative societies" and "total number of companies", with data corresponding to all 770 Andalusian municipalities for 2015. As well as the total, data were also obtained for these variables by productive sector (Table 1). All data were sourced from the Directory of Companies and Establishments held by the Institute of Statistics and Cartography of Andalusia (IECA), with the exception of the data for the primary sector, which were taken from the 2009 Agricultural Census available at the IECA. This is due to the limited nature of the data collected by the Directory of Companies and Establishments, which does not cover organisations without physical premises. 
Table 1. Main statistics.

\begin{tabular}{ccccc}
\hline $\mathbf{n}=\mathbf{7 7 0}$ & Minimum & Maximum & Average & Standard Deviation \\
\hline Primary sector cooperatives & 0 & 55 & 1.04 & 3.797 \\
Industrial cooperatives & 0 & 27 & 1.49 & 2.463 \\
Construction cooperatives & 0 & 54 & 0.61 & 2.744 \\
Service cooperatives & 0 & 284 & 3.46 & 14.069 \\
Total cooperatives & 0 & 361 & 5.56 & 18.328 \\
\hline Primary sector companies & 0 & 4759 & 319.62 & 419.925 \\
Industrial companies & 0 & 2073 & 41.05 & 127.495 \\
Construction companies & 0 & 3017 & 56.01 & 199.891 \\
Service companies & 0 & 43,366 & 514.61 & 2353.408 \\
Total companies & 7 & 48,629 & 931.29 & 2763.586 \\
\hline
\end{tabular}

Source: Compiled by the authors based on Institute of Statistics and Cartography of Andalusia (IECA) data.

\section{Results and Discussion}

This study has identified areas with positive synergies that provide comparative or competitive advantages compared to Andalusia as a whole. These municipalities offer location benefits for cooperativism due to their specific characteristics, and this is referred to as a positive residual or competitive effect.

Analysis of this differential effect on cooperativism-obtained by measuring the proportion of cooperatives relative to the total number of companies in a specific municipalityshows that around $47 \%$ of Andalusian municipalities display a positive effect (Figure 3), indicating the existence of certain factors that act as location benefits for cooperatives in comparison with the rest of the region (on the key to Figure 3, these are the municipalities with an effect $\geq 0$ ).

With regard to the intensity of this effect, or in other words, the degree of competitive difference between the municipality and the rest of the region, a particularly significant positive concentration was found in municipalities in the provinces of Huelva, Almeria and the north of Cordoba, among others, which displayed a marked comparative advantage for cooperativism compared to the rest of the region due to their specific characteristics (Figure 4).

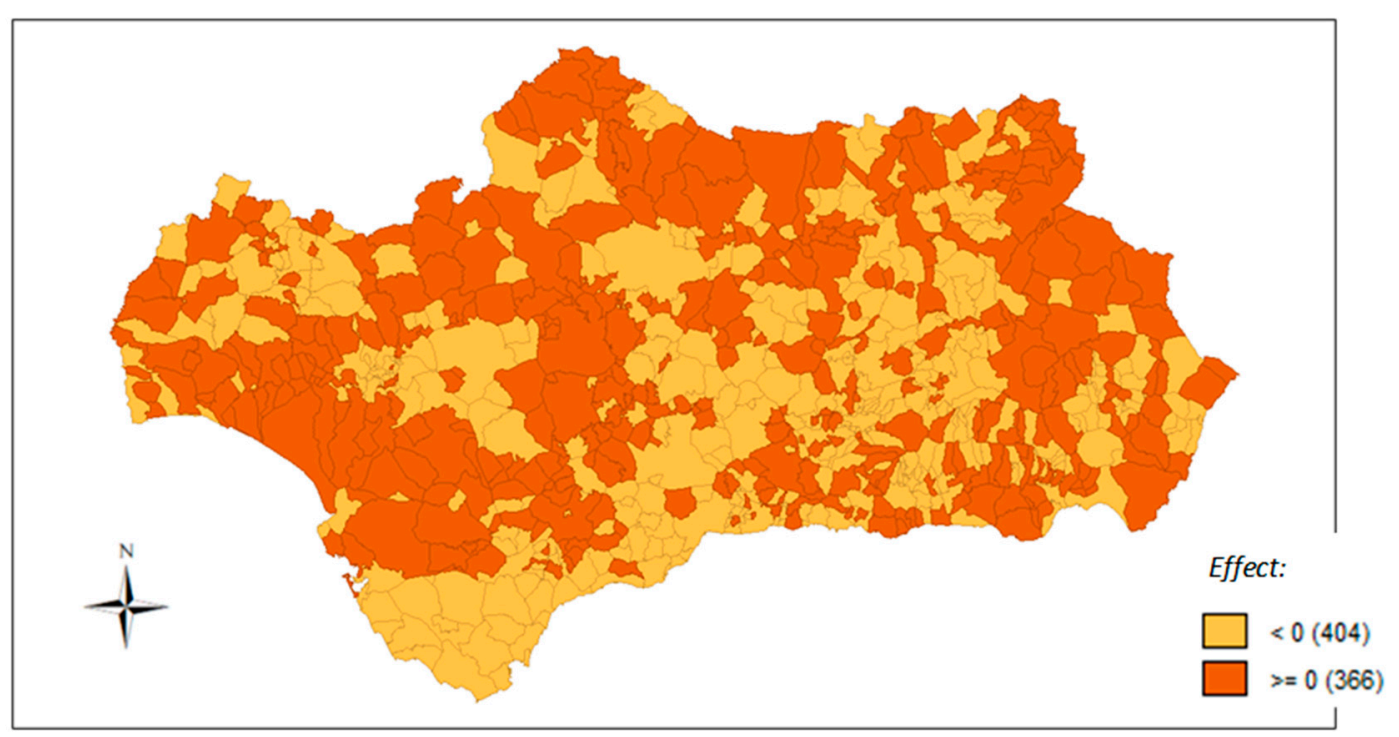

Figure 3. Residual or competitive effect on cooperativism. Source: Compiled by the authors. 


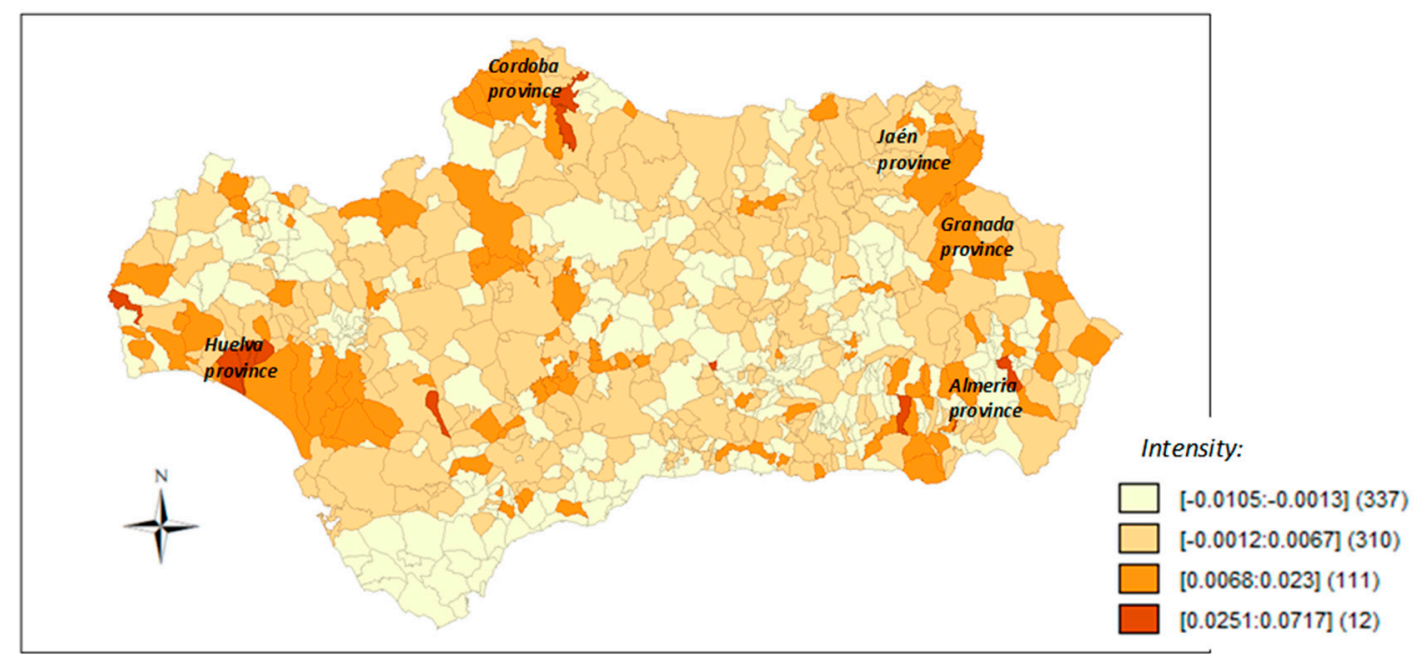

Figure 4. Intensity of the residual or competitive effect on cooperativism. Source: Compiled by the authors.

Once this concentration of the positive residual effect had been noted, local Moran's I was applied to determine whether there were any behavioural patterns-spatial clusters in the region of Andalusia - based on this competitive effect. The results obtained (Figure 5) show that there are spatial clusters in municipalities in the north of Cordoba, in rural Seville, in Huelva and in rural Almeria. A local spatial self-correlation with high values (high-high cluster) was found in only 31 of the 770 municipalities. This may indicate that these clusters offer significant location benefits and dynamic spaces for cooperativism in comparison with the rest of the region, demonstrating their immense potential for contributing to sustainable territorial development.

An analysis of the sectors in which competitive advantages are present in municipalities belonging to spatial clusters with high values (Table 2) shows that construction is the sector with a positive competitive effect in the lowest number of municipalities. This indicates that cooperative societies do not tend to operate in this sector in the same way as conventional companies do, despite the prominence of construction in the Spanish economy $-7 \%$ of jobs in the country are found in this sector, according to 2019 data from the National Statistics Institute.

As for the other sectors linked to this spatial cluster, $70 \%$ of the municipalities offer comparative advantages (residual positive effect) in the primary sector, $71 \%$ in industry and $87 \%$ in services (Table 2). The fact that most of these municipalities offer competitive advantages or location benefits in different productive sectors may suggest the presence of inter-sectoral production networks.

It is also relevant to note that in some municipalities in the province of Huelva, there is a marked differential or competitive effect in the primary and services sectors. According to the data used to conduct this analysis, the services sector contains a considerable number of cooperatives operating in retail; for example, in the municipality of Bonares, 9 of the 13 cooperatives work in this area, while 9 out of 12 cooperatives in Rociana del Condado do so.

More specifically, according to the database from the Agri-food Cooperatives organisation (previously known as the Spanish Confederation of Agricultural Cooperatives), this cluster of 12 municipalities in the province of Huelva is currently home to around 20 agricultural cooperatives. This demonstrates the importance of cooperative societies in the primary sector in response to the area's characteristics and potential. Several studies [15,61-63] have revealed the contribution made by agricultural cooperatives to sustainability; this cluster can, therefore, make a genuine contribution to sustainability in the area in which these organisations operate. 


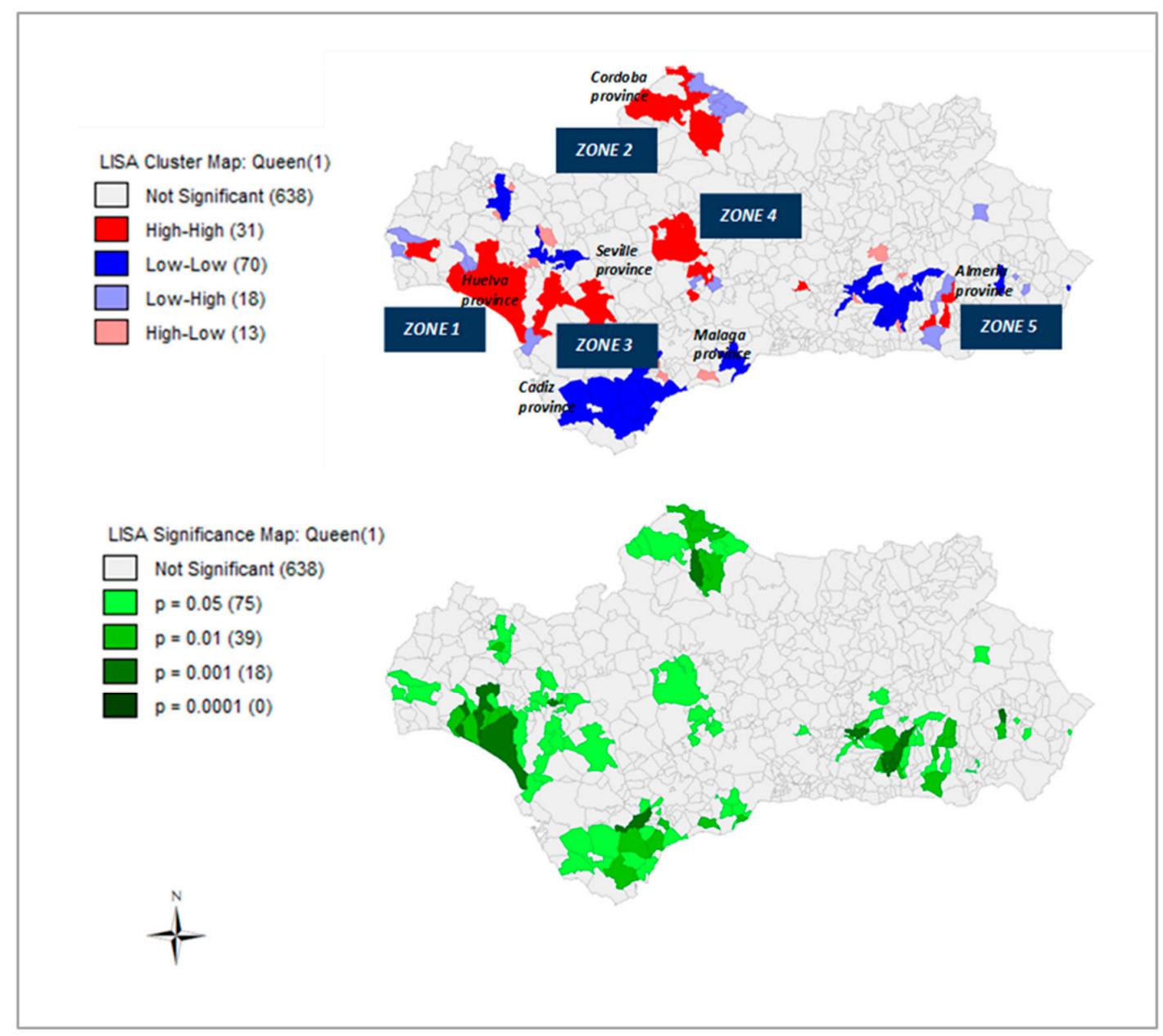

Figure 5. Local indicator of spatial association (LISA) map of spatial clusters showing the residual effect on cooperativism and significance (Consult Table 2 for the municipalities belonging to each of these zones and the map in Figure 6 for the names and locations of these municipalities). Source: Compiled by the authors.

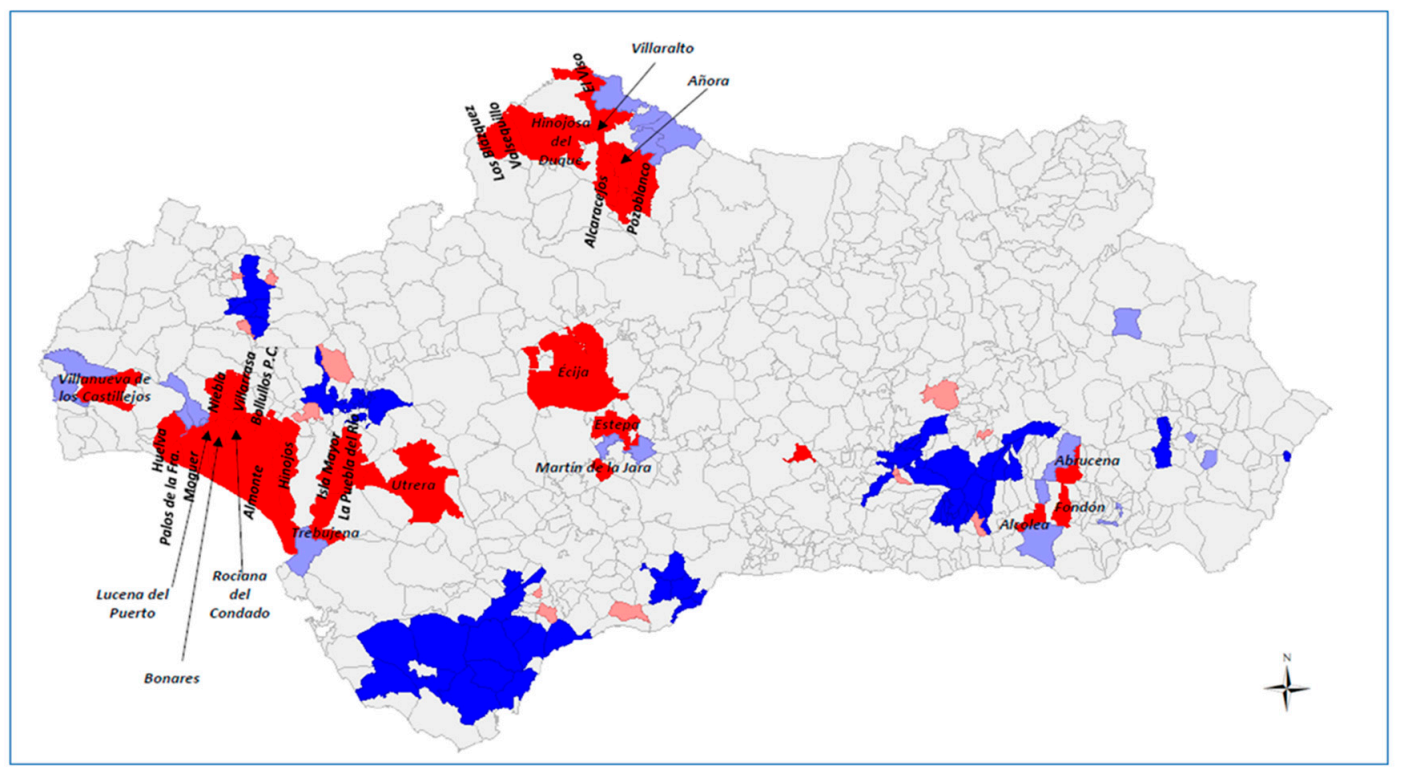

Figure 6. Map of municipalities belonging to the high residual effect cluster. Source: Compiled by the authors. 
Table 2. Sectoral breakdown of the residual effect in municipalities belonging to the high-high cluster and population.

\begin{tabular}{|c|c|c|c|c|c|c|c|c|}
\hline \multicolumn{3}{|c|}{ Location } & \multicolumn{4}{|c|}{ Breakdown by Sector } & \multirow{2}{*}{$\begin{array}{l}\text { Residual } \\
\text { Effect }\end{array}$} & \multirow{2}{*}{$\begin{array}{c}\text { No. } \\
\text { Inhabitants }\end{array}$} \\
\hline $\begin{array}{c}\text { Zone } \\
\text { on Map }\end{array}$ & Municipality & Province & Primary & Industry & Construction & Services & & \\
\hline 1 & Almonte & Huelva & 1.67676 & 0.01863 & -0.017 & 0.28099 & 1.95938 & 23,254 \\
\hline 1 & Bollullos Par del Condado & Huelva & 0.01676 & 0.11603 & 0.10034 & -0.04754 & 0.18559 & 14,324 \\
\hline 1 & Bonares & Huelva & 0.99599 & 0.06234 & -0.06152 & 2.41404 & 3.41085 & 6090 \\
\hline 1 & Hinojos & Huelva & 0.05894 & 0.37909 & -0.03384 & 0.31249 & 0.71669 & 3862 \\
\hline 1 & Huelva (capital) & Huelva & 0.00943 & -0.08191 & -0.02684 & 0.25071 & 0.15139 & 146,318 \\
\hline 1 & Lucena del Puerto & Huelva & 1.55181 & 0.23213 & -0.03856 & 1.61683 & 3.36221 & 3046 \\
\hline 1 & Moguer & Huelva & 4.12693 & 0.00323 & 0.08523 & 2.95791 & 7.17331 & 21,383 \\
\hline 1 & Niebla & Huelva & 0.14747 & 0.29979 & -0.02028 & 0.19827 & 0.62525 & 3999 \\
\hline 1 & Palos de la Frontera & Huelva & 0.1037 & -0.17988 & -0.11661 & 1.62377 & 1.43098 & 10,365 \\
\hline 1 & Rociana del Condado & Huelva & 1.1401 & 0.22378 & 0.10153 & 1.42183 & 2.88724 & 7643 \\
\hline 1 & $\begin{array}{c}\text { Villanueva de los } \\
\text { Castillejos }\end{array}$ & Huelva & 0.79472 & -0.28092 & -0.05589 & 0.09487 & 0.55278 & 2747 \\
\hline 1 & Villarrasa & Huelva & 0.32343 & 0.49414 & 0.2452 & 0.18603 & 1.24881 & 2162 \\
\hline 2 & Alcaracejos & Cordoba & 0.28012 & -0.05932 & -0.00885 & 0.98184 & 1.19379 & 1523 \\
\hline 2 & Añora & Cordoba & -0.22341 & 0.90618 & 0.68396 & 1.66905 & 3.03579 & 1563 \\
\hline 2 & Blázquez, Los & Cordoba & 0.21665 & 0.42843 & 0.43912 & -0.0905 & 0.99371 & 703 \\
\hline 2 & Hinojosa del Duque & Cordoba & -0.07787 & 0.62213 & 0.11203 & 0.62979 & 1.28608 & 7054 \\
\hline 2 & Pozoblanco & Cordoba & -0.02748 & -0.10364 & 0.0563 & 0.55278 & 0.47795 & 17,380 \\
\hline 2 & Valsequillo & Cordoba & -0.27971 & 0.71894 & -0.02518 & 0.70744 & 1.12149 & 379 \\
\hline 2 & Villaralto & Cordoba & 0.59242 & 1.32812 & -0.05156 & -0.17608 & 1.69289 & 1238 \\
\hline 2 & Viso, El & Cordoba & 0.14958 & 0.03998 & -0.0704 & 0.06191 & 0.18107 & 2651 \\
\hline 3 & Trebujena & Cadiz & 0.36413 & 0.41537 & 0.13483 & 0.25134 & 1.16567 & 7072 \\
\hline 3 & Puebla del Río, La & Seville & 0.92736 & -0.15588 & 0.19473 & 0.28377 & 1.24998 & 12,114 \\
\hline 3 & Utrera & Seville & 0.31563 & -0.04036 & 0.10098 & -0.00429 & 0.37196 & 52,558 \\
\hline 3 & Isla Mayor & Seville & -0.00416 & 0.66017 & 0.47572 & 0.45634 & 1.58806 & 5938 \\
\hline 4 & Écija & Seville & 0.35408 & 0.1177 & -0.04674 & 0.08559 & 0.51064 & 40,320 \\
\hline 4 & Estepa & Seville & -0.00017 & -0.05148 & 0.24595 & 0.00047 & 0.19476 & 12,716 \\
\hline 4 & Martín de la Jara & Seville & 0.03646 & 0.89769 & -0.0334 & 0.08597 & 0.98671 & 2756 \\
\hline 5 & Abrucena & Almeria & -0.26046 & 0.48211 & 0.27105 & 0.23699 & 0.72968 & 1279 \\
\hline 5 & Alcolea & Almeria & 0.43033 & 0.56845 & -0.03008 & 0.61041 & 1.57911 & 812 \\
\hline 5 & Fondón & Almeria & -0.18129 & 0.64753 & -0.05206 & 0.75468 & 1.16886 & 1020 \\
\hline
\end{tabular}

Source: Compiled by the authors based on 2015 IECA data.

If we compare the results obtained here with those of the third Andalusian Regional Development Report [56], different spatial areas were obtained according to the variables used in each study. However, similar results were identified in some cases: according to the report, the south of Huelva province is one of the areas with the most significant increases in agricultural employment during the 2000-2006 period, with a growth rate of $10 \%-40 \%$. The municipality of Moguer stands out, in particular, with growth exceeding $40 \%$. This result echoes our own findings, in which this area emerged as one of the most significant in terms of competitive advantages and location benefits for cooperative societies, especially in the primary sector.

Meanwhile, the report also shows an increase in the number of companies working in ecological agriculture from 2000 to 2008 of more than 50\% in municipalities like Hinojosa del Duque in Cordoba province (belonging to Zone 2, one of the clusters obtained in this study); between $10 \%$ and $50 \%$ in Almonte, Rociana del Condado and Huelva (Huelva province) (municipalities belonging to our Zone 1 cluster) and more than 50\% in Écija (Seville province, Zone 4 cluster). This may indicate that the cooperative sector is making headway in the ecological agriculture industry, or that cooperatives are serving as economic drivers and producing comparative advantages or location benefits in these areas.

Moreover, if we consider the population of these municipalities belonging to the cluster with high values, 50\% have fewer than 5000 inhabitants; according to the Law on Sustainable Development of the Rural Environment, they may, therefore, be described as 
small rural municipalities (Table 2). These areas offer comparative advantages for cooperative societies and should be included in any development policies that are implemented in rural parts of Andalusia. According to Sánchez-Zamora and Gallardo-Cobos [52], these policies should take into account the specific characteristics of each rural area. They also show that economic, social, human and natural capital help to generate resilient territorial processes in rural Andalusia. Based on this idea, cooperative societies offer a significant opportunity to build resilience and make a robust contribution to territorial sustainability due to their close relationships with their surroundings.

\section{Conclusions}

Given the importance of cooperativism in the Spanish autonomous community of Andalusia, this study aimed to determine whether certain areas in the region offer location benefits for cooperative societies, which have been shown in previous research to contribute to sustainable development.

Driven by their own principles and values, cooperative societies are organisations that are embedded in the environments in which they operate, using an area's endogenous resources while striving to meet its needs. This link between cooperative societies and territory means that these enterprises may be viewed as agents of sustainable territorial development.

As for whether or not there are favourable environments offering location benefits for cooperatives, the methods applied showed that certain areas in Andalusia offer greater facilities for these organisations than the rest of the region. The study makes a methodological contribution, adapting the shift-share analysis to study the proportion of cooperative societies relative to the total number of companies, before examining the residual or competitive effect produced by the results. Following this, local Moran's I was applied to the results on the competitive effect, understood as the presence of location benefits in an area (or municipality in this case) if it is positive, to identify the places that are favourable to this type of organisation (spatial clusters).

The results showed that in some areas with positive synergies for cooperativism, agricultural activities generate spatial clusters with a positive differential or competitive effect, while the construction sector plays a far lesser role (in most of the municipalities belonging to the high-value cluster, the competitive effect was negative for this sector, showing that there are no location benefits for this type of cooperative).

Moreover, $50 \%$ of the municipalities with a favourable environment for cooperativism (belonging to spatial clusters with a high residual or competitive effect) may be described as small rural municipalities according to the classification contained in the Law on Sustainable Development of the Rural Environment in Spain.

On the one hand, the literature has shown that cooperative societies contribute to sustainable territorial development, while on the other, the results obtained in this study reveal that some areas offer a comparative advantage for cooperativism. These areas are predominantly rural. The findings of the study represent an interesting contribution to the literature, as they provide justification for the inclusion of social economy enterprises in strategies and policies aiming to encourage and boost sustainable development.

Another of the contributions made by the study is a territorial map of Andalusia showing areas of comparative advantage that offer location benefits for cooperative societies, providing a tool to inform the application of local development initiatives and development policies involving these enterprises.

However, the study also had certain limitations. The analysis carried out was static in nature, making it impossible to analyse the evolution of cooperative societies in the region.

In terms of future lines of research, it would be pertinent to explore the factors that are conducive to the emergence of cooperative societies. This study has identified favourable environments for cooperatives, which offer certain location benefits; therefore, it would be useful to identify these beneficial factors as well as those that hinder the development of these enterprises in order to adopt specific measures to encourage their emergence. 
For the aforementioned reasons, it is important to highlight the existence of areas with a greater predisposition to cooperativism and the role played by cooperatives in holistic sustainable territorial development.

Author Contributions: Conceptualization, M.d.C.P.-G. and L.V.-P.; methodology, L.V.-P.; formal analysis, M.d.C.P.-G. and L.V.-P.; writing—original draft preparation, M.d.C.P.-G. and L.V.-P.; writingreview and editing, M.d.C.P.-G. and L.V.-P. All authors have read and agreed to the published version of the manuscript.

Funding: This research received no external funding.

Institutional Review Board Statement: Not applicable.

Informed Consent Statement: Not applicable.

Data Availability Statement: This study analyzed publicly available datasets. This data can be found here: http:/ / www.juntadeandalucia.es/institutodeestadisticaycartografia, https://www.ine.es/.

Conflicts of Interest: The authors declare no conflict of interest.

\section{References}

1. Stiglitz, J. El Malestar en la Globalización; Taurus: Madrid, Spain, 2002.

2. Stiglitz, J. El Precio de la Desigualdad; Santillana Ediciones Generales: Madrid, Spain, 2014.

3. Pecqueur, B.; Itçaina, X. Économie sociale et solidaire et territoire: Un couple allant de soi? Rev. Int. l'Economie Soc Recma. 2012, 325, 48-64. [CrossRef]

4. Vázquez-Barquero, A.; Rodríguez-Cohard, J.C. Local development in a global world: Challenges and opportunities. Reg. Sci. Policy Pract. 2019, 11, 885-897. [CrossRef]

5. CEP-CMAF-Comité Économique et Social Européen. Déclaration Finale Commune des Organisations Européennes de L'économie Sociale: 20 June 2002. Available online: https://www.eesc.europa.eu/resources/docs/qe-30-12-790-fr-c.pdf (accessed on 2 January 2021).

6. Ley 5/2011, de 29 de marzo, de Economía Social. Boletín Oficial del Estado n 76 de 30 de marzo de. 2011, pp. $33023-33033$. Available online: http:/ / www.boe.es/boe/dias/2011/03/30/pdfs/BOE-A-2011-5708.pdf (accessed on 4 June 2020).

7. Puentes, R.; Velasco, M. Importancia de las sociedades cooperativas como medio para contribuir al desarrollo económico, social y medioambiental, de forma sostenible y responsable. REVESCO Rev. Estud. Coop. 2009, 99, 104-129. [CrossRef]

8. Cuñat, R.; Coll, V. ¿Contribuyen las cooperativas de reciente creación al desarrollo local? Una visión desde los principios cooperativistas. Rev. Venez. Econ. Soc. 2007, 13, 8-29.

9. Calvo, R.; González, J. The Creation of Social Economy Companies in the Model of Local Development: Reflections on the Present Case Valencian Divergence. REVESCO Rev. Estud. Coop. 2011, 104, 7-37. [CrossRef]

10. Demoustier, D. Les concepts philosophiques et sociaux de l'ESS dans ses rapports à l'activité économique et aux territoires. In Économie Sociale et Solidaire: Animation et Dynamiques des Territoires; A. Ndiaye, L'Harmattan: Paris, France, 2011 ; pp. 47-60.

11. Draperi, J.F. Comprendre l'économie Sociale. Fondements et Enjeux; Dunod: Paris, France, 2014.

12. Guzmán, C.; Santos, F.J.; Barroso, M. Cooperativismo, factor empresarial y desarrollo económico: Propuesta de un modelo teórico de enlace. REVESCO Rev. Estud. Coop. 2016, 122, 110-134.

13. Rodríguez-Cohard, J.C.; Mozas Moral, A.; Bernal Jurado, E. Desarrollo local por Cooperativas: Diversificación productiva en el ámbito rural andaluz: El caso de Bedmar. REVESCO Rev. Estud. Coop. 2002, 76, 173-190.

14. Cuadrado, M.; Ciruela, A.M. Cooperatives and labor companies as an engine of economic and social development: Analysis of their economic impact on the region of Andalusia. REVESCO Rev. Estud. Coop. 2014, 115, 57-100.

15. Galdeano-Gómez, E.; Pérez-Mesa, J.C.; Godoy-Durán, Á. The social dimension as a driver of sustainable development: The case of family farms in southeast Spain. Sustain. Sci. 2016, 11, 349-362. [CrossRef]

16. Blanco, M. Effects of the Economic Crisis of 2008 on Employment in Andaluzas Cooperatives: A Study of Provincial Impact Analysis by Shift-Share. CIRIEC Esp. Rev. Econ. Públ. Soc. Coop. 2017, 91, 175-201. [CrossRef]

17. Pérez González, M.C.; Valiente Palma, L. The "Business-Territory" Relationship of cooperative societies as compared to the conventional business sector in the region of Andalusia. Ann. Public Coop. Econ. 2020, 91, 565-583. [CrossRef]

18. National Statistics Institute. Economically Active Population Survey. 2020. (In Spanish). Available online: https://www.ine.es/ dyngs /INEbase/en/operacion.htm?c=Estadistica_C\&cid=1254736176918\&menu=ultiDatos\&idp=1254735976595 (accessed on 10 September 2020).

19. Garofoli, G. Desarrollo económico, organización de la producción y territorio. In Desarrollo Económico Local en Europa; Vázquez, A., Garofoli, G., Eds.; Colegio de Economistas: Madrid, Spain, 1995; pp. 113-123.

20. Alburquerque, F. Teoría y práctica del enfoque del desarrollo local. Obs. Iberoam. del Desarro. Local y la Econ. Soc. 2003, 25, 1-24.

21. Boisier, S. Desarrollo territorial y descentralización: El desarrollo en el lugar y en las manos de la gente. Eure 2004, 30, 27-40. [CrossRef] 
22. Vázquez Barquero, A. Desarrollo endógeno. Teorías y políticas de desarrollo territorial. Investig. Reg. 2007, 11, 183-210.

23. Lowe, P.; Phillipson, J.; Proctor, A.; Gkartzios, M. Expertise in rural development: A conceptual and empirical analysis. World Dev. 2019, 116, 28-37. [CrossRef]

24. Rural Enterprise and Neo-Endogenous Development. Available online: https://pure.sruc.ac.uk/en/publications/ruralenterprise-and-neo-endogenous-development (accessed on 1 January 2021).

25. Shucksmith, M. Disintegrated Rural Development? Neo-Endogenous Rural Development, Planning and Place-Shaping in Diffused Power Contexts. Sociol. Ruralis 2010, 50, 1-14. [CrossRef]

26. Gkartzios, M.; Scott, M. Placing Housing in Rural Development: Exogenous, Endogenous and Neo-Endogenous Approaches. Sociol. Ruralis 2014, 54, 241-265. [CrossRef]

27. Bosworth, G.; Annibal, I.; Carroll, T.; Price, L.; Sellick, J.; Shepherd, J. Empowering Local Action through Neo-Endogenous Development; The Case of LEADER in England. Sociol. Ruralis 2016, 56, 427-449. [CrossRef]

28. Cejudo, E.; Navarro, F. (Eds.) Neoendogenous Development in European Rural Areas; Springer Nature Switzerland AG: Cham, Switzerland, 2020; ISBN 978-3-030-33462-8. [CrossRef]

29. Luffiego García, M.; Rabadán Vergara, J.M. La evolución del concepto de sostenibilidad y su introducción en la enseñanza. Ensen. de las Cienc. 2000, 18, 473-486.

30. Vázquez-Barquero, A. Las Nuevas Fuerzas Del Desarrollo; Antoni Bosch: Barcelona, Spain, 2005.

31. Alburquerque, F. Metodología Para el Desarrollo Económico Local. 1994. Available online: https://www.ucipfg.com/ Repositorio/MGTS/MGTS14/MGTSV-05/semana5/complementarios/TDES_Albuquerque_2_Unidad_4_1_.pdf (accessed on 5 September 2020).

32. Vázquez Barquero, A. Desarrollo endógeno: Mecanismos institucionales y culturales. Rev. Valen. D' Estud. Auton. 1997, 21, 71-92.

33. Mozas Moral, A.; Bernal Jurado, E. Desarrollo Territorial y Economía Social. CIRIEC Esp. Rev. Econ. Públ. Soc. Coop. 2006, 55, 125-140.

34. Bastida, M.; Vaquero García, A.; Cancelo Márquez, M.; Olveira Blanco, A. Fostering the Sustainable Development Goals from an Ecosystem Conducive to the SE: The Galician's Casde. Sustainability 2020, 12, 500. [CrossRef]

35. Fernandez-Guadaño, J.; Lopez-Millan, M.; Sarria-Pedroza, J. Cooperative Entrepreneurship Model for Sustainable Development. Sustainability 2020, 12, 5462. [CrossRef]

36. Pérez de Uralde, J.M. La adecuación de las sociedades cooperativas en las estructuras de desarrollo local. REVESCO Rev. Estud. Coop 1999, 68, 143-151.

37. Da Silva, L.X.; Ratzmann, V. El cooperativismo y su comportamiento frente al capitalismo. Coop. y Desarro. $2008,93,82-102$.

38. Pérez González, M.C. Desarrollo Local y Economía Social. In Teorías y estrategias de Desarrollo Local; Barroso, M., Flores, D., Eds.; Universidad Internacional de Andalucía: Sevilla, Spain, 2010; pp. 271-306.

39. Buendía Martínez, I. Las sociedades cooperativas en el marco de las iniciativas públicas de desarrollo rural: Un análisis del caso español. REVESCO Rev. Estud. Coop. 1999, 68, 75-94.

40. Buendía-Martínez, I.; Côté, A. Desarrollo territorial rural y cooperativas: Un análisis desde las políticas públicas. Cuad. Desarro. Rural 2014, 2, 35-54. [CrossRef]

41. Pérez González, M.C.; Valiente Palma, L. Aproximación al perfil y calidad del empleo generado por las sociedades cooperativas andaluzas. REVESCO Rev. Estud. Coop. 2019, 130, 122-148. [CrossRef]

42. Bastida, M.; Pinto, L.H.; Olveira Blanco, A.; Cancelo, M. Female Entrepreneurship: Can Cooperatives Contribute to Overcoming the Gender Gap? A Spanish First Step to Equality. Sustainability 2020, 12, 2478. [CrossRef]

43. Bel Durán, P.; Cabaleiro Casal, M.J. La sociedad cooperativa: Fórmula empresarial idónea para el desarrollo rural endógeno y sostenible. Rev. Española de Estud. Agrosoc. y Pesq. 2002, 194, 9-25.

44. Morales Gutiérrez, A.C. La construcción de capital social a través de la economía social: El caso andaluz. REVESCO Rev. Estud. Coop. 2002, 78, 89-120.

45. Disparidades, Competitividad Territorial y Desarrollo Local y Regional en América Latina. Available online: https: / repositorio. cepal.org/handle/11362/7286 (accessed on 2 September 2020).

46. Aché, D.B. Teorías que explican la formación de desigualdades territoriales. Rev. Geogr. Venez. 2013, 54, $179-194$.

47. Ortiz-Pérez, S. La Producción Campesina de un Espacio Cooperativo: Dinámicas Territoriales Hacia Una Soberanía Alimentaria. Ph.D. Thesis, Universidad de Alicante, Alicante, Spain, April 2014.

48. Todes, A.; Turok, I. Spatial inequalities and policies in South Africa: Place-based or people-centred? Prog. Plann. 2018, $123,1-31$. [CrossRef]

49. Lo Cascio, I.; Mazzola, F.; Di Giacomo, G.; Epifanio, R. Territorial capital and the economic crisis: The role of spatial effects. In Proceedings of the 53rd Congress of the European Regional Science Association: "Regional Integration: Europe, the Mediterranean and the World Economy", Palermo, Italy, 27-31 August 2013.

50. Mastronardi, L.; Giagnacovo, M.; Romagnoli, L. Bridging regional gaps: Community-based cooperatives as a tool for Italian inner areas resilience. Land Use Policy 2020, 99, 104979. [CrossRef]

51. Filippi, M.; Triboulet, P.; Chantelot, S.; Peres, S. The Spatial Distribution of French Agricultural Cooperatives: An Exploratory Spatial Data Analysis. Eur. Plan. Stud. 2015, 23, 710-732. [CrossRef]

52. Sánchez-Zamora, P.; Gallardo-Cobos, R. Diversity, Disparity and Territorial Resilience in the Context of the Economic Crisis: An Analysis of Rural Areas in Southern Spain. Sustainability 2019, 11, 1743. [CrossRef] 
53. Caravaca Barroso, I.; González Romero, G.; Mendoza Bonet, A. Indicadores de dinamismo, innovación y desarrollo: Su aplicación en ciudades pequeñas y medias de Andalucía. Bol. la Asoc. Geogr. Esp. 2007, 43, 131-154.

54. Méndez, R.; Melero, A.; Calatrava, A. Desarrollo territorial policéntrico y ciudades intermedias: Recursos productivos y dinámicas económicas locales en Andalucía. Estud. Geogr. 2008, 69, 637-663. [CrossRef]

55. Sánchez-Zamora, P.; Gallardo-Cobos, R.; Ceña-Delgado, F. El medio rural andaluz frente a la crisis económica: Un análisis de los factores de resiliencia territorial. Econ. Agrar. y Recur. Nat. 2014, 14, 27-56. [CrossRef]

56. Pita, F.; Pedregal, B. Tercer Informe de Desarrollo Territorial de Andalucía; Secretariado de Publicaciones de la Universidad de Sevilla: Sevilla, España, 2011.

57. Dunn, E.S. A statistical and analytical technique for regional analysis. Pap. Reg. Sci. 1960, 6, 97-112. [CrossRef]

58. Anselin, L. Local Indicators of Spatial Association-LISA. Geogr. Anal. 1995, 27, 93-115. [CrossRef]

59. Duncan, R.P. Competition and the Coexistence of Species in a Mixed Podocarp Stand. J. Ecol. 1991, 79, 1073-1084. [CrossRef]

60. Longley, P.A.; Tobón, C. Spatial dependence and heterogeneity in patterns of hardship: An intra-urban analysis. Ann. Assoc. Am. Geogr. 2004, 94, 503-519. [CrossRef]

61. Díaz, J.A. Las cooperativas y el desarrollo sostenible. COODES Coop. y Desarro. 2013, 1, 53-69.

62. Giagnocavo, C.; Galdeano-Gómez, E.; Pérez-Mesa, J.C. Cooperative Longevity and Sustainable Development in a Family Farming System. Sustainability 2018, 10, 2198. [CrossRef]

63. Mozas, A. Contribución de las Cooperativas Agrarias al Cumplimiento de los Objetivos de Desarrollo Sostenible; Especial Referencia al Sector Oleícola; Ciriec-España: Valencia, Spain, 2019. 